University of the District of Columbia School of Law

Digital Commons @ UDC Law

\title{
The 'New Selma' and the Old Selma: Arizona, Alabama, and the Immigration Civil Rights Movement in the Twenty-first Century
}

Kristina M. Campbell

University of the District of Columbia David A Clarke School of Law, kristina.campbell@udc.edu

Follow this and additional works at: https://digitalcommons.law.udc.edu/fac_journal_articles

Part of the Human Rights Law Commons, Immigration Law Commons, and the Law and Race Commons

\section{Recommended Citation}

35 Journal of American Ethnic History, 76 (Spring 2016)

This Article is brought to you for free and open access by the Publications at Digital Commons @ UDC Law. It has been accepted for inclusion in Journal Articles by an authorized administrator of Digital Commons @ UDC Law. For more information, please contact lawlibraryhelp@udc.edu. 
See discussions, stats, and author profiles for this publication at: https://www.researchgate.net/publication/301482591

\section{The "New Selma" and the Old Selma: Arizona, Alabama, and the Immigration Civil Rights Movement in the Twenty-First Century}

Article in Journal of American ethnic history · April 2016

DOI: 10.5406/jamerethnhist.35.3.0076

CITATION

READS

1

202

1 author:

。

Kristina M Campbell

University of the District of Columbia

7 PUBLICATIONS 56 CITATIONS

SEE PROFILE 


\section{Immigration \& Ethnic \\ History Society}

The "New Selma" and the Old Selma: Arizona, Alabama, and the Immigration Civil Rights Movement in the Twenty-First Century

Author(s): Kristina Campbell

Source: Journal of American Ethnic History, Vol. 35, No. 3 (Spring 2016), pp. 76-81

Published by: University of Illinois Press on behalf of the Immigration \& Ethnic History Society

Stable URL: http://www.jstor.org/stable/10.5406/jamerethnhist.35.3.0076

Accessed: 05-12-2016 23:11 UTC

\section{REFERENCES}

Linked references are available on JSTOR for this article:

http://www.jstor.org/stable/10.5406/jamerethnhist.35.3.0076?seq=1\&cid=pdf-

reference\#references_tab_contents

You may need to $\log$ in to JSTOR to access the linked references.

JSTOR is a not-for-profit service that helps scholars, researchers, and students discover, use, and build upon a wide range of content in a trusted digital archive. We use information technology and tools to increase productivity and facilitate new forms of scholarship. For more information about JSTOR, please contact support@jstor.org.

Your use of the JSTOR archive indicates your acceptance of the Terms \& Conditions of Use, available at http://about.jstor.org/terms

University of Illinois Press, Immigration \& Ethnic History Society are collaborating with JSTOR to digitize, preserve and extend access to Journal of American Ethnic History 


\title{
The "New Selma" and the Old Selma: Arizona, Alabama, and the Immigration Civil Rights Movement in the Twenty-First Century
}

\author{
KRISTINA CAMPBELL
}

IN APRIL 2010, WHEN ARIZONA PASSED its infamous antiimmigrant law, SB 1070, many commenters-including myself-observed that, in the struggle for immigrants' rights, Arizona had become to Latinos what Alabama was to African Americans during the Civil Rights struggle of the 1950s and 1960s. ${ }^{1}$ More specifically, Arizona was dubbed the "New Selma" in recognition of the importance of the Bloody Sunday events during the Selma to Montgomery March on March 7, 1965, in the fight for the passage of the Voting Rights Act (VRA) in August 1965. ${ }^{2}$ Now, on the fiftieth anniversary of both the Selma March and the passage of the VRA, we are still awaiting comprehensive immigration reform at the federal level. ${ }^{3}$ As Congress continues to deprive the millions of unauthorized migrants living and working in the United States the opportunity to regularize their immigration status, and as the racist and xenophobic undertones of antiimmigrant rhetoric only increase over time, ${ }^{4}$ the similarities between the New Selma and Old Selma as a cultural flash point in the struggle for equality and human dignity become more and more pronounced.

In his unfinished manuscript, "The Politics of Expulsion: A Short History of Alabama's Anti-Immigrant Law, HB 56," the late Raymond A. Mohl, Distinguished Professor of History at the University of Alabama at Birmingham, directly and succinctly identified the true nature of the motivations behind the passage of HB 56 in the Alabama legislature. Professor Mohl observed that "nativist fears of large numbers of ethnically different newcomers, especially over job competition and unwanted cultural change, sometimes referred to as 'cultural dilution,' provided political cover for politicians who sought to control and regulate immigration within state borders, but also to push illegal immigrants out." 5 By recognizing that $\mathrm{HB}$ 56 and other anti-immigrant laws that followed nationwide in the wake of SB 1070 were driven by racist and nativist politicians, ${ }^{6}$ Professor Mohl cut

76 Journal of American Ethnic History $\quad$ Spring 2016 Volume 35, Number 3

(C) 2016 by the Board of Trustees of the University of Illinois 
directly to the issue when he commented that "the state's harsh, aggressive, and discriminatory anti-immigrant policy also brought back memories from a half-century earlier, when state-sponsored racial discrimination targeted African Americans."

At the heart of the connection between the New Selma and the Old Selma is the attempt by politicians in both eras to limit the civil rights of persons of color by passing discriminatory laws-African Americans in the Old Selma, and Latinos in the New Selma. Due in large part to the high-profile United States Supreme Court case challenging SB 1070 in $2012,{ }^{8}$ Arizona's status as the New Selma was cemented in the public's imagination as "ground zero" of the immigrants' civil rights movement in this century. ${ }^{9}$ However, Professor Mohl's manuscript is an important contribution to the scholarly literature because his discussion of HB 56 not only situates Alabama's anti-immigrant law within the state's unique history of racial segregation and discrimination, but it also begs the question: To what extent has the culture of the Old Selma influenced the "New Nativism" 10 of the South? And is the state of Arizona - fraught with its own long history of anti-Latino sentiment in the Southwest - really the New Selma of the immigrants' civil rights movement?

While not making the claim outright, Professor Mohl's manuscript nonetheless makes a compelling case that the state of Alabama-not Arizona - represents the true spirit of the fight against the anti-immigrant laws targeting Latinos across the country in the first decade of the twenty-first century. In discussing the genesis of Arizona's SB 1070 and the influence of the law's architect, Kansas politician Kris Kobach, Professor Mohl details how Kobach was approached by Alabama politicians seeking his assistance in crafting an anti-immigrant law for Alabama, which had recently seen an influx of Latinos to the state. ${ }^{11}$ He then discusses the ways in which HB 56, which was signed by the governor in June 2011, was an even more aggressive effort to fulfill Kobach's vision of "attrition through enforcement"-or self-deportation of immigrants, a policy position once endorsed by 2012 Republican presidential candidate Mitt Romney ${ }^{12}$ - than SB 1070. Startling in sweep and breathtaking in scope, HB 56 was as comprehensive as it was cruel: The law not only made it a crime for undocumented persons to reside in the state of Alabama and denied them access to almost every public service in Alabama, it also required public schools to verify the immigration status of children, which Professor Mohl notes was unique among the anti-immigrant laws of the era and almost certainly in contravention of the U.S. Supreme Court decision in Plyler v. Doe $e^{13}$ guaranteeing free public education elementary and secondary education to children, regardless of 
immigration status. ${ }^{14}$ The admitted racist and nativist motivations of Michael Hethmon of the Federation for American Immigration Reform (FAIR), and Hethmon's own statements about his long-term strategy reasons for including the public school status-check provision in HB 56, are the best evidence of the link between the discriminatory intent of HB 56 and Jim Crow Era laws targeting African Americans in Alabama. ${ }^{15}$

However, it is the collective response to HB 56-by civil rights groups, faith communities, and concerned citizens in Alabama - that provides the strongest argument that the spirit of Selma remains in Alabama in the nationwide struggle for immigrant civil rights. Not only does Professor Mohl's manuscript detail the swift condemnation of HB 56 and the unintended economic consequences of the law in Alabama due to the fact that terrified Latinos fled the state following the law's passage, ${ }^{16}$ but it also discusses the courage displayed by those opposed to the law in the face of vehement nativist and xenophobic rhetoric. ${ }^{17}$ The hostility faced by those who spoke out against the law cannot be understated. Indeed, the situation in Alabama was so critical at one point following the passage of HB 56 that the U.S. Department of Justice (DOJ) sent federal monitors to the state to document any potential violation of civil rights and civil liberties that were occurring in Alabama as a result of the law's enforcement. ${ }^{18}$ However, people of principle and conscience remained undeterred in their efforts against HB 56. Professor Mohl describes how many "diverse" groups in Alabama were "galvanized" by the passage of HB 56, worked together to overcome the deleterious effects of the law, and joined in the legal efforts to get it struck down in the courts. ${ }^{19}$ He notes in his manuscript how several prominent publications, including the New York Times, observed that the passage of HB 56 had ushered in "a new Alabama civil rights movement focused on immigrant rights." 20

This commentary by those watching the situation unfolding in Alabama after the enactment of HB 56-that the Old Selma is actually the New Selma - underscores the link between the African American Civil Rights Movement of the past, the immigration civil rights movement of the present, and the importance of the state of Alabama in both movements. One of the criticisms leveled at the Department of Justice's (DOJ) legal strategy in United States v. Arizona, the 2012 Supreme Court case that ultimately reaffirmed the supremacy of federal immigration law over the states, was that, despite the ultimate success of the DOJ's legal arguments, the preemption theory that struck down SB 1070 did not get to the real issue behind anti-immigrant laws - that such laws are motivated by racism, xenophobia, and discriminatory intent against Latinos and other people of color. ${ }^{21} \mathrm{By}$ 
contrast, the Eleventh Circuit Court of Appeals decision enjoining enforcement of HB 56 found that " "there was substantial evidence that the law was adopted with discriminatory intent against Latinos,' and that Alabama's legislators "conflated race and immigration status."' 22 Ultimately, the Eleventh Circuit Court also held that HB 56 violated the Equal Protection Clause of the Fourteenth Amendment, and that, in its passage of HB 56, Alabama had "crafted a calculated policy of expulsion." 23

That this pronouncement about the undeniable link between race, immigration status, and equal protection under the law was delivered against Alabama's anti-immigrant law — and not the infamous Arizona "Show Me Your Papers" law ${ }^{24}$ - makes Professor Mohl's unfinished manuscript about HB 56 even more critical to our understanding of the history of race, law, and social movements in the American South. Unlike Arizona, Alabama is not known for its history of discrimination against Latinos-when one thinks of the history of racially discriminatory laws in the state of Alabama, one thinks of laws targeting African Americans in the Jim Crow South. However, Professor Mohl correctly identifies HB 56 as consistent with Alabama's history of engaging in "politics of expulsion"-laws that are designed to intimidate, harass, and appeal "to xenophobic fears of racial diversity, cultural change, and economic competition." 25

The anti-immigrant movement in Alabama has been called by some as "Arizona on steroids," ${ }^{26}$ and Professor Mohl opined that HB 56 "brought nativism and xenophobia into the political mainstream in Alabama." ${ }^{27}$ But in mainstream media and culture, the story of how HB 56 was born and died is not nearly as well known as that of its forebear and counterpart in Arizona, SB 1070. Without detracting from the importance of the passage of SB 1070 in Arizona to the emergence of immigration as a new civil rights issue for the twenty-first century, the untold story of HB 56 in the immigration civil rights movement is one that should be heard. I am thankful to Professor Mohl for starting the conversation about the relevance of HB 56 to the continuing struggle for Latinos' and immigrants' rights in our country, and grateful to him for shedding light on the prospect that, in this new civil rights movement, the Selma of yesterday is also the Selma of today.

\section{NOTES}

1. Chad G. Marzen, "Hispanics in the Heartland: The Fremont, Nebraska Immigration Ordinance and the Future of Latino Civil Rights," Harvard Journal on Racial and Ethnic Justice 29 (Spring 2013): 69-93. 
2. Ibid.; AZ BluMeanie, "50th Anniversary of 'Bloody Sunday' in Selma this Saturday," Blog for Arizona, March 3, 2015, http://blogforarizona.net/50th-anniversary-of-bloody -sunday-in-selma-this-saturday/.

3. Philip E. Wolgin, "2 Years Later, Immigrants Are Still Waiting on Immigration Reform," Center for American Progress, June 24, 2015, https:/www.americanprogress.org/issues/ immigration/news/2015/06/24/115835/2-years-later-immigrants-are-still-waiting-on -immigration-reform/.

4. Kristina M. Campbell, "A Dry Hate: White Supremacy and Anti-Immigrant Rhetoric in the Humanitarian Crisis on the U.S.-Mexico Border," West Virginia Law Review 117, no. 3 (2015), http://papers.ssrn.com/sol3/papers.cfm?abstract_id=2517558; W.W., "Donald Trump's Xenophobia: Divide and Conquer,' Economist, July 8, 2015, http://www.economist .com/blogs/democracyinamerica/2015/07/donald-trumps-xenophobia.

5. Raymond A. Mohl, "The Politics of Expulsion: A Short History of Alabama's AntiImmigrant Law, HB 56," Journal of American Ethnic History 35, no. 3 (Spring 2016): 42.

6. Ian Gordon, "The Immigration Hardliner Family Tree: A Guide to the Funders, Think Tanks, Lawyers, and Politicians behind Harsh Arizona-Style Legislation," Mother Jones, March/April 2012, http://www.motherjones.com/politics/2012/03/john-tanton-anti -immigration-laws.

7. Mohl, "Politics of Expulsion," 42.

8. Arizona v. United States, 567 U.S.

9. Kristina M. Campbell, "The Road to S.B. 1070: How Arizona Became Ground Zero for the Immigrants' Rights Movement and the Continuing Struggle for Latino Civil Rights in America," Harvard Latino Law Review 14 (Spring 2011): 1-21.

10. Benjamin Richard Knoll, "Understanding the New Nativism: Causes and Consequences for Immigration Policy Attitudes in the United States" (PhD diss., University of Iowa, 2010), http://ir.uiowa.edu/etd/532/.

11. Mohl, "Politics of Expulsion," 45.

12. Lucy Madison, "Romney on Immigration: 'I'm for Self-Deportation,'” CBS News, January 24, 2012, http://www.cbsnews.com/news/romney-on-immigration-im-for-self -deportation/.

13. 457 U.S. 202 (1982).

14. Mohl, Politics of Expulsion," 47.

15. Ibid.

16. Ibid., 48.

17. Ibid.

18. Ibid., 52.

19. Ibid.

20. Ibid., 52.

21. Gabriel J. Chin and Kevin R. Johnson, "Profiling's Enabler: High Court Ruling Underpins Arizona Immigration Law," Washington Post, July 13, 2010, http://www.washingtonpost .com/wp-dyn/content/article/2010/07/12/AR2010071204049.html.

22. Southern Poverty Law Center, "Alabama's Anti-Immigrant Law Dealt Yet Another Major Blow," December 12, 2011, http://www.splcenter.org/get-informed/news/alabama-s -anti-immigrant-law-dealt-yet-another-major-blow, quoted in Mohl, "Politics of Expulsion," 53. 
23. Campbell Robertson and Julia Preston, "Appeals Court Draws Boundaries on Alabama Immigration Law," New York Times, August 21, 2012, http:/www.nytimes.com/2012/08/22/ us/appeals-court-limits-alabamas-immigration-law.html, quoted in Mohl, "Politics of Expulsion," 55.

24. Mohl, "Politics of Expulsion," 44-45.

25. Ibid., 56.

26. Michael A. Olivas, foreword to Ediberto Roman, Those Damned Immigrants: America's Hysteria over Undocumented Immigration (New York: New York University Press, 2013), xi.

27. Mohl, "Politics of Expulsion," 58. 